\title{
SCHÖNWARLING/SKOWARCZ AND DOLLKEIM/ KOVROVO-TYPE CROSSBOW FIBULAE IN THE SAMBIAN-NATANGIAN CULTURE AREA
}

\section{JAROSLAW A. PRASSOLOW, ${ }^{1,2, *}$ KONSTANTIN SKVORTSOV ${ }^{2}$}

\author{
${ }^{1}$ Zentrum für Baltische und Skandinavische Archäologie, Stiftung Schleswig-Holsteinische Landesmuseen Schloss Gottorf, \\ DE-24837 Schleswig, Germany \\ ${ }^{2}$ Institute of Archaeology of the Russian Academy of Sciences, Dmitriia Ul'ianova St 19, RU-117036, Moscow, Russia
}

\section{Keywords}

Sambian-Natangian culture, Museum, Migration period, Schönwarling/ Skowarcz-type fibulae, Dollkeim/Kovrovo-type fibulae, chronology.

\begin{abstract}
The article is devoted to Schönwarling/Skowarcz and Dollkeim/Kovrovo-type crossbow fibulae with a long narrow foot and a full catch-plate, one of the most characteristic chronotypes of the Migration Period. The authors describe a number of specific construction features of the fibulae in the Sambian-Natangian culture area, which define their typological placement. Based on the results of a comparative analysis of prewar and modern archaeological sources, the authors propose an up-to-date specified chronology of these types. Contrary to the currently popular hypothesis, the analysed archaeological material in the Sambian-Natangian area does not demonstrate co-existence, but instead the smooth replacement of Schönwarling/Skowarcz fibulae by those of the Dollkeim/Kovrovo type in the transition phase D2/D3, i.e. about 430 AD.
\end{abstract}

\section{Introduction}

Crossbow fibulae with a long narrow foot and a full catchplate belong to the most widespread artefacts of SambianNatangian culture $\left(\mathrm{SNC}^{1}\right)$ of the Early Migration period (period D). ${ }^{2}$ The main forms are: fibulae of Schönwarling/

\footnotetext{
1 Often referred to in West European archaeological literature as Dollkeim-Kovrovo culture according to the definition given by its investigator Wojciech Nowakowski (1996). At the end of the 1 st/2nd to the 6th centuries $\mathrm{AD}$, archaeological monuments of SNC were spread throughout the modern Kaliningrad Peninsula (until 1946, the Sambian Peninsula), as well as the areas to the south and east, which in prewar times formed the central part of the former German province of East Prussia, and nowadays the modern Kaliningrad region of Russia.

2 In this paper, the authors use the chronological system proposed by Otto Tischler and further specified by Heinrich Kemke (Tischler and Kemke 1902; Kemke 1914), as well as the chronological constructions of Kazimierz Godłowski (1970, 1974), with later specifications and additions by Wojciech Nowakowski (1996), Anna Bitner-Wróblewska (2001, pp. 1419, 89-120), Jerzy Okulicz-Kozaryn (1973; 1988), Jacek Kowalski (1991), and Konstantin Skvortsov (2010). In general, the
}

\footnotetext{
* Corresponding author. E-mail: jaroslaw.prassolow@zbsa.eu
}

DOI: http://dx.doi.org/10.15181/ab.v27i0.2177

Received 18.05.2020; Revised 15.06.2020; Accepted 10.08.2020
Skowarcz type, fibulae of Dollkeim/Kovrovo type (S/S and $\mathrm{D} / \mathrm{K}$ respectively), and an 'intermediate variant'. All three forms are represented in archaeological material mostly by bronze fibulae, while silver and iron specimens are found far less often. ${ }^{3}$ While bronze and silver artefacts possess a cast catch-plate, their iron counterparts have a forged catch-plate.

The above-mentioned types were spread over the whole Baltic Sea basin in period D, not only in the region of their probable emergence (the SNC area) but also in the area of contemporary archaeological cultures of modern

dating used in the text for the SNC area is as follows: phase D1, 350/36-375/400; phase D2, 375/400-430; phase D3, 430450/500; period E, 450/500-650/675; phase E1, 450/500-520 $\mathrm{AD}$.

3 In the actual paper, the authors refer only to bronze and silver artefacts whose better state of preservation facilitates the development of more precise typological reconstructions. 
Lithuania and Poland, as well as on the Baltic Sea islands, ${ }^{4}$ and to a lesser degree in Latvia, Estonia and Finland (Bitner-Wróblewska 2001, pp. 34-39, 41-55, Figs. 3, 6, 7). ${ }^{5}$

The development of a modern, possibly detailed, typology of the fibulae in question, as well as the definition of the chronological framework of their existence, is thus important for the dating of archaeological complexes in the whole Baltic Sea basin.

\section{Research history}

The investigation of the crossbow fibulae in question has a long history. Local researchers in the former German province of East Prussia in the early stages of archaeological studies (late 18th and early 19th century) distinguished crossbow fibulae with long and short catch-plates (Fibel mit Nadelscheide and Fibel mit kurzem Nadelhalter respectively) (Tischler and Kemke 1902). However, no formal definition of types was given, and neither was a description of their most typical criteria made in the prewar period of research.

In the postwar era, a significant contribution to the discussion on the classification and chronological framework of crossbow fibulae with a narrow long foot in the SNC area was made by the Polish researchers Godłowski (1970; 1974) and Nowakowski (1996). Godłowski dated the fibulae in question to the whole period D (1970, pp. 54-55, Pl. 12). Nowakowski dated (according to the illustrative material in his book) the appearance of crossbow fibulae with a short catch-plate to an earlier period, i.e. phase 4 of his chronology of Dollkeim-Kovrovo culture (1996, Table 107). Phase 4 corresponds to the beginning of period $\mathrm{D}$ (phase C3) of the chronology of Godłowski, which in turn covers the first three quarters of the 4th century AD' (Nowakowski 1996, p. 52). ${ }^{6}$ On the other hand, in the text of his book, he dates the 'Schönwarling' crossbow fibulae to phase 5, i.e. to the end of the 4 th century, $460 \mathrm{AD}$ (Nowakowski 1996, p. 53). Also, the crossbow fibulae with

\footnotetext{
${ }^{4}$ While one of the two main concentrations of S/S fibulae is known to be situated in the SNC area, finds of D/K fibulae were previously believed to be far less numerous here (BitnerWróblewska 1991a, pp. 233-236; 1991c, pp. 253, 256; 1992, pp. 30-31). However, modern data do not confirm this statement: $\mathrm{D} / \mathrm{K}$ fibulae are also widely represented in the archaeological material of the SNC in the epoch under consideration.

5 In the framework of this publication, the authors investigate relevant finds from the territory of SNC, while later on, similar investigations should be performed on archaeological material from the neighbouring territories of modern Lithuania and Poland. A final comparative analysis of these research results will show whether the conclusions drawn are true for the whole distribution area of the fibulae under consideration, or whether there are local deviations as far as chronological aspects and the use of these artefacts are concerned.

6 Translation by Prassolow.
}

a long catch-plate were dated by him to phase 5 (Nowakowski 1996, Tab. 107).

A further significant contribution to the investigation of crossbow fibulae was made by the German researcher Mechthild Schulze-Dörrlamm, who developed a typology of 5th and 6th-century AD crossbow fibulae for the territories west of the Rhine and south of the Danube. Along with the other crossbow fibulae, Schulze-Dörrlamm described a new type: Schönwarling (1986, pp. 650-652). Their wide spring, rather short bow, semi-circular in profile, with a cast, rather small, handle for the axis of the spring and a long narrow tapering foot with a short, full catch-plate, are typical of crossbow fibulae of this type (Schulze-Dörrlamm 1986, pp. 650-651). Schulze-Dörrlamm pointed out the existence of numerous bronze, far rarer iron specimens of this type. Also, she mentions additional known variants of the type: fibulae with a faceted bow and a pseudo-twisted upper surface of the foot, as well as fibulae whose surface is decorated with transverse brass or silver inlaid grooves. The researcher dated the emergence of the Schönwarling type to the second third of the 5th century, while she believed the transition from the 5 th to the 6 th century was the latest period in which these fibulae were used (Schulze-Dörrlamm 1986, pp. 651-652).

These results were taken into account by the Polish archaeologist Bitner-Wróblewska when she investigated the archaeological material from the Migration Period in the Baltic Sea basin (1991a; 1991b; 1991c; 1992; 2001). ${ }^{7}$ Bitner-Wróblewska pointed out the differences in the construction of Schönwarling/Skowarcz fibulae (she adapted the name of the fibulae of the Schönwarling type to the modern geopolitical realities, with Schönwarling being a German, and Skowarcz a Polish, designation of the same place) and those of Dollkeim/Kovrovo type, which she had already independently defined in local archaeological material herself (2001, p. 50). Although originally the D/K fibulae were named after the flat burial site of Dollkeim/ Kovrovo, this name correlates perfectly with the wide spread of the artefacts in question over the whole area of the SNC, also known as Dollkeim-Kovrovo culture, in the developed-late phases of the Early Migration period. The $\mathrm{D} / \mathrm{K}$ fibulae can indeed be found in almost all burial sites that have a period $\mathrm{D}$ burial zone.

Bitner-Wróblewska believes the presence of the long narrow foot and the full catch-plate to be the most important typological traits of both types of crossbow fibulae in question. Further characteristic (although not typologically determinant) traits, according to Bitner-Wróblewska, are: semispherical, often profiled at the base, or cylindrical knobs on the ends of a wide spring of ten to 14

\footnotetext{
The authors thank Bitner-Wróblewska for the fruitful scientific discussions and provision of additional information concerning the topic of actual publication.
} 


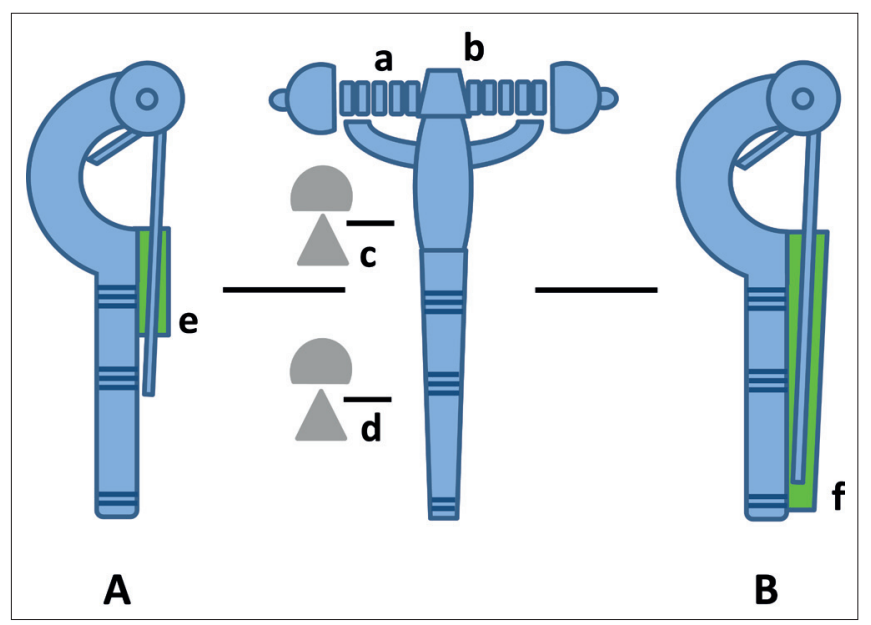

Figure 1. Crossbow fibulae with a full catch-plate. A. Schönwarling/Skowarcz type; B. Dollkeim/Kovrovo type: a. spring; b. head; c. bow with cross-section; d. foot with cross-section; e. short catch-plate; f. long catch-plate. Not to scale.

coils, as well as a short, frequently decorated bow with a semi-spherical or triangular cross-section. The main construction and typological difference between the $S / S$ and $\mathrm{D} / \mathrm{K}$ fibula types is the length of the catch-place, i.e. the proportion of its length to the total length of the fibulae foot (Fig. 1). The S/S and D/K fibula types demonstrate the shortest and the longest catch-plates respectively, while those of the 'intermediate variant' have catch-plates of intermediate length (Bitner-Wróblewska 2001, pp. 41-42).

Bitner-Wróblewska treats the fibulae in question, quite reasonably, as links in one and the same typological sequence, with $\mathrm{S} / \mathrm{S}$ and $\mathrm{D} / \mathrm{K}$ being its typological earlier and later forms, respectively. This said, she postulates the almost contemporary emergence and use of fibulae of both types in the Baltic Sea basin. However, she mentions that fibulae of Dollkeim/Kovrovo type could also be found in the slightly younger burial complexes, if compared with specimens of S/S type, and may thus have remained in use for slightly longer. For the SNC area, the researcher dates them to phases $\mathrm{C} 3-\mathrm{D} / \mathrm{E}$, i.e. she dates their appearance to the end of the 4th century AD (Bitner-Wróblewska 2001, pp. 40, 50-51, Pl. LIX).

These conclusions by Bitner-Wróblewska regarding the chronology of the crossbow fibulae in question are based primarily on an analysis of 4 burial complexes: graves 106 and 183 in the cemetery at Dollkeim (today Kovrovo), and graves 41 and 60 in the cemetery at Warnikam (today Pervomaĭskoe) in the former SNC area. In addition, Bitner-Wróblewska takes into account fibulae in the hoards from Eschweiler (on the border of modern France and Germany), dated to the end of the 4th century, and from Frauenburg (Frombork in modern Poland), dated no later than $430 \mathrm{AD}$ (2001, pp. 39-40, 50). ${ }^{8}$

\footnotetext{
8 It should also be stressed that the principles of hoard composition are quite different to those of grave inventories. There-
}

Russian researchers also took part in the discussion concerning the chronological framework of the $\mathrm{S} / \mathrm{S}$ and $\mathrm{D} / \mathrm{K}$ fibulae in the local SNC context (Kulakov 1990, p. 23, Fig. 12 ; 2003, p. 276, Figs. 88-89). However, the relevant publications by Bitner-Wróblewska remain the most competent and quoted information sources so far.

\section{Modern research sources}

Since the publication of the above-mentioned monograph by Bitner-Wróblewska (2001), a large amount of additional archaeological material has been introduced into the research. These finds originate from archaeological excavations both in cemeteries, which were already known in the prewar period of research, and from archaeological monuments that were discovered after 1945 (Fig. 2). The most fully investigated, and at the same time the largest and most important cemeteries are: Dollkeim/Kovrovo, Hünenberg/Dobroe, Lauth/Bol'shoe Isakovo, Kleinheide/ Gur'evsk, Shosseinoe/Warthen (Gusakov et al., 1987; Kulakov 1994; 2007; 2017; Kulakov and Tiurin 2005; Kulakov and Skvortsov 2000; Skvortsov 1996; 1997; 1999; 2000; 2001; 2003; 2004; 2008; Skvorzov 2007; Prassolow 2017; 2018 , pp. $223,248,252,255-256,284$ ). It should also be mentioned that, along with the fact that in recent decades new excavations have been performed on already-known cemeteries, the much higher standards of documentation of archaeological material distinguish modern research from that of the prewar period, and make a reliable and full reconstruction of the grave inventories possible.

In addition, since the 1990s, researchers have regained access to a number of data sources which for a long pe-

fore, the dating of the hoards, which is based exclusively on the analysis of their content, always has a certain element of uncertainty regarding their upper chronological limit. 
riod were believed to have been lost forever. The most significant of these sources are the numerous rediscovered finds and archival documents from the famous PrussiaMuseum in Königsberg. Large parts of the former collection and archive are currently preserved in the Berlin Museum of Ancient and Early History (Museum für Vorund Frühgeschichte [MVF], Staatliche Museen zu Berlin, Stiftung Preußischer Kulturbesitz), in the Kaliningrad Regional Museum of History and Art (Kaliningradskii oblastnoı̆ istoriko-khudozhestvennyı̆ muzeĭ), and in the Olsztyn Museum of Warmia and Mazuria (Muzeum Warmii i Mazur). Further important data sources, which contain numerous and detailed illustrations, are the personal archives of Marta Schmiedehelm and Feliks Jakobson, preserved in Tallinn (Tallinna Ülikooli arheoloogia teaduskogu arhiiv) and Riga (Latvijas Nacionālais vēstures muzejs) respectively (Prassolow 2018, pp. 27-32).

The last category of data sources, which have been used by the authors of the actual publication for the analysis of the archaeological material in question, are archaeological papers and exhibition catalogues from both the prewar and postwar research periods.

\section{Actual research questions}

A modern comparative analysis of the currently available archaeological data from the SNC area demonstrates the necessity to revise some research questions that until recently were believed to have already been answered. One of these questions is the definition of the chronological framework for certain fibula types from the Late Roman and Early Migration periods.

The results of an analysis performed on the currently available archaeological material, including that from the latest excavations on the Kaliningrad (until 1946 Sambian) Peninsula, confirm the main conclusions made by Bitner-Wróblewska. However, the authors see a possibility for making additional observations on a number of important research issues concerning the construction, and primarily the chronological framework, of $\mathrm{S} / \mathrm{S}$ and $\mathrm{D} / \mathrm{K}$ fibulae in the SNC area.

A certain morphological heterogeneity in $\mathrm{S} / \mathrm{S}$ and $\mathrm{D} / \mathrm{K}$ types is present in modern publications on the archaeology of the SNC area. The real reason for this is insufficient consistency by their authors concerning the practical application of typological criteria formulated by Bitner-Wróblewska. While the length of the full catchplate remains the main typological trait of these fibulae, undeservedly little attention is paid to parameters such as the total length of the fibula and the cross-section of their bows. This said, the authors consider only medium-size fibulae $^{9}$ with bows with a faceted (multangular), sub-tri-

9 The length of currently known cast $\mathrm{D} / \mathrm{K}$ fibulae varies from 3.5 to $7.5 \mathrm{~cm}$, the width from 2.0 to $4.6 \mathrm{~cm}$, while their height is angular or semi-circular cross-section to be representative of $\mathrm{S} / \mathrm{S}$ or $\mathrm{D} / \mathrm{K}$ types in the 'classic' understanding of them (Fig. 1). At the same time, it is doubtful whether smaller fibulae with flat bows also belong to the types in question.

Another question, which so far remains unanswered, is the typological relationship between $\mathrm{S} / \mathrm{S}$ or $\mathrm{D} / \mathrm{K}$ fibulae made of bronze or silver on the one hand, and iron specimen of these types on the other (Bitner-Wróblewska 2001, p. 45). It should still be clarified whether iron fibulae are local, cheaper copies of the popular bronze and silver fibulae, or if they represent imported goods from the territories of other archaeological cultures.

To sum up, the authors prefer to follow the definition types of our Polish colleague, and not to apply it to artefacts, which do not possess the whole spectrum of 'classic' typological traits, and thus not artificially 'blur' the typological and chronological framework of the fibula types in question.

These aspects gain particular importance once we consider the use of the crossbow fibulae in question as chronotypes for the dating of burial complexes in the SNC area. If the hypothesis of the almost contemporary use of fibulae of both types were true, one would expect the existence of numerous burial complexes with joint finds of $S / K$ and $\mathrm{D} / \mathrm{K}$ fibulae. However, this assumption is not confirmed by the local archaeological material: such properly documented joint finds are extremely rare (see Table 1).

In fact, it would be more accurate to say that these two fibula types mark an invisible border between earlier burial complexes that stand in the tradition of the Late Roman period and the early phase of the Early Migration period, and those that are typical of the end of the Early and the Late Migration period (periods D and E respectively).

The S/S fibulae are predominantly found in graves ${ }^{10}$ whose inventories include 'large crossbow fibulae' of 161-162 type (große $A B F$ ) (Almgren 1897, pp. 77-78; Prassolow 2018 , p. 51, Fig. 13), trapeze- and star-footed fibulae ${ }^{11}$ (the latter of types 2 and 4) (Bitner-Wróblewska 1991a; 2001,

about 1.3 to $2.6 \mathrm{~cm}$. The ratio of the length to the width may thus vary from 1:1 to 2:1. Similar indicators for the bronze and silver specimen of S/S type are: length 4.0 to $8.0 \mathrm{~cm}$, width 2.6 to $4.3 \mathrm{~cm}$, height about 1.9 to $2.3 \mathrm{~cm}$. The size of the iron fibulae, which are not a subject of discussion in this paper, usually exceeds the given values due to the manufacturing method of the fibulae.

${ }^{10}$ At least in the SNC area, pairs of the fibulae in question are usually found in graves which are identified, on the basis of the grave inventories, as female burials. In male graves, these types are, as a rule, either represented by single specimens, or are found in combination with fibulae of other types.

${ }^{11}$ In this instance, it is necessary to point out the similarity in the construction of the catch-plates of fibulae of type S/S with trapeze- and star-footed fibulae, which indicates the use of common technological schemes of manufacture, as well as a typological connection between these costume elements. 


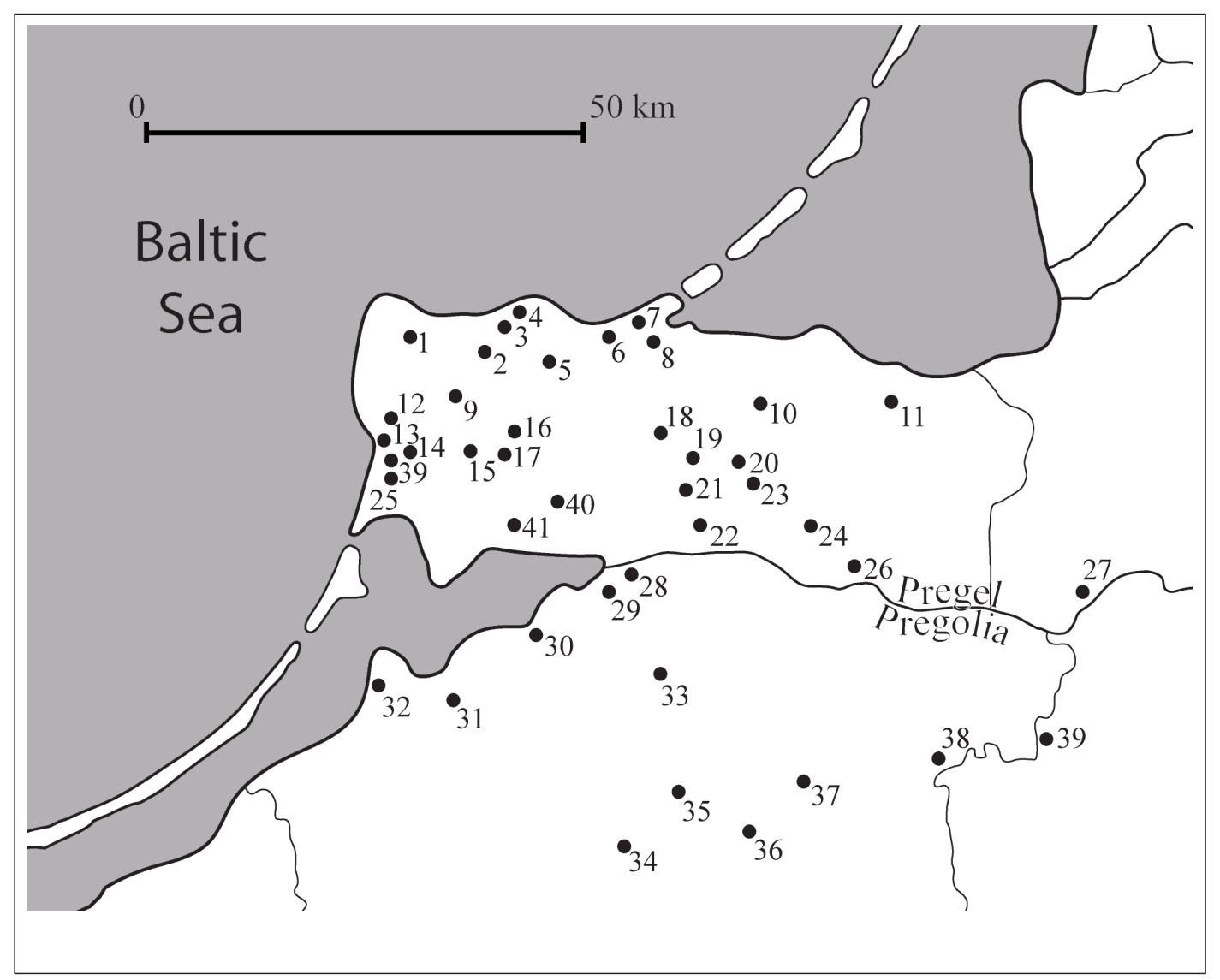

Figure 2. Finds of Dollkeim/Kovrovo fibulae in flat cemeteries in the SNC area according to modern data: 1. Kraam/Grachëvka; 2. Pokirben; 3. Schlakalken/Zaostrov'e; 4. Hünenberg/Dobroe; 5. Eisliethen/Geroǐskoe; 6. Dollkeim/Kovrovo; 7. Wiskiauten/Mokhovoe; 8. Friedrichswalde/Kamenka; 9. Siegesdicken; 10. Molsehnen/Kosmodem’ianskoe; 11. Löbertshof; 12. Kirpehnen/Povarovka; 13. Grebieten/Okunëvo; 14. Sacherau/Morozovka; 15. Klein Medenau/Logvino; 16. Seefeld/Prostornoe; 17. Warengen; 18. Stantau/ Mitino; 19. Kleinheide/Gur'evsk; 20. Trausitten/Gur'evsk-1; 21. Neudamm/Vasil'kovo; 22. Lauth/Bol'shoe Isakovo; 23. Fürstenwalde/Poddubnoe; 24. Kadgiehnen/Prudy; 25. Bahnau/Tikhorechenskoe; 26. Popelken/Prudovka; 27. Stobingen/Pridorozhnoe; 28. Shosseı̌noe-2; 29. Warthen/Shosseĭnoe; 30. Tengen/Ushakovo-1; 31. Warnikam/Pervomaĭskoe; 32. Balga/Vesëloe; 33. Ernsthof/ Krasnopartizanskoe; 34. Wackern/Elanovka; 35. Wogau/Lermontovo; 36. Gross Sausgarten/Berëzovka; 37. Gross Waldek /Osokino; 38. Detlevsruh; 39. Korjeiten/Putilovo; 40. Greibau; 41. Polwitten/Rovnoe. The prewar and modern names of the cemeteries are indicated.

pp. 61-65; Prassolow 2018, pp. 50-52, Fig. 13), necklaces and bracelets with a circular cross-section (types $\mathrm{H} 2$ and A1 respectively) (Prassolow; see 2018, pp. 64, 66 -67, Fig. $17)$, tongue-shaped strap ends and buckles with a rectangular ferrule, decorated in a local variant of the Sösdala style (Bitner-Wróblewska 2001, p. 109; Prassolow 2018, pp. 62-63), and buckles with an oval, thickened frame (Group H) (Madyda-Legutko 1986, pp. 63-69, 72-74; Prassolow 2018, pp. 54-60, Figs. 14-16) (Fig. 3.A). Knifedaggers (types 1 and 2), which are dated to phases D1-D2, are common finds in male graves of this horizon (Prassolow 2013, pp. 65-66, Fig. 5; 2018, pp. 97-103, 110-111, Figs. 33-35).

Fibulae of $\mathrm{D} / \mathrm{K}$ type, on the contrary, are found in graves together with archaeological material from a younger period: fibulae with a crosspiece at the foot end, typical of phase E1 (Åberg 1919, pp. 122, 124; Rudnicki 2008; Skvortsov 2010, pp. 41-47; Prassolow 2018, pp. 53-54,
Fig. 13), twisted necklaces and bracelets (types H3 and A2 respectively) (Prassolow 2018, pp. 65, 67, Fig. 17), belt buckles with a kidney-shaped frame (type 3.2) (MadydaLegutko 1986, pp. 66-67, 72; Butenas 1999, pp. 37-38, Fig. 2; Prassolow 2018, pp. 56-58, 60-61, Figs. 14, 15), ceramic vessels of the 'classic' bottle-shaped form (type 8 , variant 2), as well as vessels of the earlier transitional form (type 8, variant 1) (Prassolow; see 2018, p. 42. Fig. 10) (Fig. 3b). The typologically late forms of knife-daggers (type 3) (Prassolow 2013, pp. 65-66, Fig. 5; 2018, pp. 104$105,112-113$, Figs. 33-35) are also characteristic of these graves, which can confidently be dated to phase D3 -transition phase D3/E1.

Until now, only single joint finds of S/S and D/K fibulae are known to have been made in graves in the SNC area. It should additionally be noted that the majority of currently known graves of this kind are either not properly 
Table 1. A selection of burial complexes from the SNC area with Dollkeim/Kovrovo and Schönwarling/Skowarcz-type fibulae.

\begin{tabular}{|c|c|c|c|c|c|c|}
\hline Cemetery & $\begin{array}{c}\text { Grave } \\
\text { Nr. }\end{array}$ & $\begin{array}{l}\text { Dollkeim/ } \\
\text { Kovrovo type } \\
\text { fibulae }\end{array}$ & $\begin{array}{c}\text { Schönwarling/ } \\
\text { Skowarcz type } \\
\text { fibulae }\end{array}$ & $\begin{array}{c}\text { Fibulae of } \\
\text { intermedieate } \\
\text { variant }\end{array}$ & $\begin{array}{l}\text { Other } \\
\text { fibula } \\
\text { types }\end{array}$ & $\begin{array}{l}\text { Archives, } \\
\text { Literature }\end{array}$ \\
\hline Hünenberg/Dobroe & 124 & 2 & & & & $\begin{array}{l}\text { Kulakov 2014, } \\
\text { 220, Fig. } 51\end{array}$ \\
\hline \multirow[t]{9}{*}{ Lauth/Bol'shoe Isakovo } & 20 & & 1 & & $\begin{array}{l}1 \text { star-footed } \\
\text { fibula }\end{array}$ & KS-A \\
\hline & 41 & 2 & & & & KS-A \\
\hline & 43 & 2 & & & & KS-A \\
\hline & 56 & 2 & & & & KS-A \\
\hline & 61 & 2 & & & & KS-A \\
\hline & 100 & & 1 & & $\begin{array}{c}2 \text { fibulae of } \\
\text { the } 161-162 \\
\text { type }\end{array}$ & KS-A \\
\hline & 118 & 2 & & & & KS-A \\
\hline & 147 & 2 & & & & KS-A \\
\hline & 182 & 2 & & & & KS-A \\
\hline \multirow[t]{11}{*}{ Dollkeim / Kovrovo } & 42 & 2 & & & & FJ-A \\
\hline & 45 & & 2 & & & FJ-A \\
\hline & $91 \mathrm{a}$ & 2 & & & & FJ-A \\
\hline & 106 & 1 & 1 & & & FJ-A \\
\hline & 112 & 1 (0 after MS-A) & & 1 (2 after MS-A) & & FJ-A, MS-A \\
\hline & 113 & 2 & & & & FJ-A \\
\hline & 119 & 1 & & & $\begin{array}{l}1 \text { fibula with } \\
\text { a crosspiece } \\
\text { on the foot } \\
\text { end }\end{array}$ & FJ-A \\
\hline & 128 & 1 & 1 & & & MS-A \\
\hline & 155 & 1 (0 after MS-A) & & 1 (2 after MS-A) & & FJ-A, MS-A \\
\hline & 178 & 2 (1 after MS-A ) & & 0 (1 after MS-A) & & FJ-A, MS-A \\
\hline & 180 & & 2 & & & FJ-A, MS-A \\
\hline \multirow[t]{5}{*}{ Grebieten / Okunëvo } & 3 & & (3?) & & & FJ-A, MS-A \\
\hline & $22(\mathrm{X})$. & 2 & & & & FJ-A, MS-A \\
\hline & 49 & & 1 & & $\begin{array}{l}1 \text { trapeze- } \\
\text { footed fibula }\end{array}$ & FJ-A \\
\hline & 175 & & 1 & & $\begin{array}{c}1 \text { trapeze- } \\
\text { footed fibula }\end{array}$ & FJ-A, MS-A \\
\hline & $\begin{array}{c}97 \\
(1907)\end{array}$ & 2 & & & & FJ-A \\
\hline $\begin{array}{l}\text { Gross Sausgarten / } \\
\text { Berëzovka }\end{array}$ & 32 & 2 & & & & FJ-A \\
\hline $\begin{array}{l}\text { Siegesdicken / } \\
\text { Svetlogorsk }\end{array}$ & II.6 & 2 & & & & FJ-A \\
\hline \multirow[t]{2}{*}{$\begin{array}{l}\text { Warnikam / } \\
\text { PervomaǏskoe }\end{array}$} & 13 & 2 & & & & \\
\hline & 72 & 2 & & & & \\
\hline
\end{tabular}




\begin{tabular}{|c|c|c|c|c|c|c|}
\hline Cemetery & $\begin{array}{l}\text { Grave } \\
\text { Nr. }\end{array}$ & $\begin{array}{l}\text { Dollkeim/ } \\
\text { Kovrovo type } \\
\text { fibulae }\end{array}$ & $\begin{array}{c}\text { Schönwarling/ } \\
\text { Skowarcz type } \\
\text { fibulae }\end{array}$ & $\begin{array}{c}\text { Fibulae of } \\
\text { intermedieate } \\
\text { variant }\end{array}$ & $\begin{array}{l}\text { Other } \\
\text { fibula } \\
\text { types }\end{array}$ & $\begin{array}{l}\text { Archives, } \\
\text { Literature }\end{array}$ \\
\hline & 42 & & 2 & & $\begin{array}{l}1 \text { trapeze- } \\
\text { footed fibula }\end{array}$ & FJ-A \\
\hline $\begin{array}{l}\text { Schlakalken / } \\
\text { Iaroslavskoe }\end{array}$ & 35 & $2(?)$ & & & & FJ-A \\
\hline Korjeiten / Putilovo & 187 & 2 & & & & MS-A \\
\hline Eisliethen / GeroĬskoe & 249 & & 2 & & & MS-A \\
\hline \multirow{2}{*}{$\begin{array}{l}\text { Greibau / Liublino - } \\
\text { Krasnopol'e }\end{array}$} & 249 & $2(?)$ & & & & MS-A \\
\hline & 258 & 2 & & & & MS-A \\
\hline \multirow[t]{2}{*}{ Polwitten / Rovnoe } & 86 & $2(?)$ & & & & MS-A \\
\hline & 102 & $2(?)$ & & & & MS-A \\
\hline
\end{tabular}

documented, or represent 'borderline cases' as far as their dating is concerned.

\section{A reassessment of a popular hypothesis}

Let us now take a closer look at the four funerary complexes which up to now have formed the basis of the relative chronology of the crossbow fibulae under consideration (Bitner-Wróblewska 2001, p. 50, as well as personal communication).

\section{Dollkeim/Kovrovo cemetery, grave 106}

According to data published by Tischler and Kemke, the inventory of grave 106 (original designation U9) (SMBPK/MVF, PM-A 0245/01, PDF: Seite 8; 13; ;2, SMB-PK/ MVF, PM-A 0245/02, PDF: Seite 17) consisted of the following goods: '... a funeral urn, a further ceramic vessel (the presence of 1 more vessel is doubtful), a crossbow fibula (V21,13 BA 453 ${ }^{14}$ ), a crossbow fibula (BA 431, similar to V11), a small buckle with a ferrule, etc' (Tischler and Kemke 1902, p. 22). From the records of Schmiedehelm, it follows that 'etc' denotes a knife, an awl (which is most likely to be a firesteel) and a biconical amber bead (Fig. $4 a)$, which were probably seen by Schmiedehelm during her visit to the Prussia-Museum.

\footnotetext{
${ }^{12}$ The modern designations of the documents from the archive of the former Prussia-Museum, which are currently preserved in the MVF museum in Berlin.

${ }^{13}$ The designation of the artefacts in the tables of the original publication (Tischler and Kemke 1902).

${ }^{14}$ Hereinafter see the illustrations in the 'Berlin Album' (Günther and Voss 1880), with BA as its abbreviation.
}

The records in the archive of the Prussia-Museum document the finding of only 2 objects: a cremation urn (SMBPK/MVF, PM-A 0245/02,) and a silver object (beads? ${ }^{15}$ ) under a regular round-shaped stone pavement on the grave.

Jakobson's archive contains data on the presence of an additional smaller amber bead, as well as of melted glass beads with red and yellow stripes in the grave inventory. In his notes, the researcher mentions that both crossbow fibulae were made of bronze. The most informative source for us is a sketch of the grave goods made by Jakobson, which confirms the conclusion of Bitner-Wróblewska concerning the typological placement of the fibulae in the grave to $S / S$ and $D / K$ types respectively (Fig. $4 \mathrm{~b}$ ).

The available data on the goods in the grave do not allow us to date the complex more precisely than to period D, or to attribute it to the 'early' or 'late' horizons of the crossbow fibulae under consideration.

\section{Dollkeim/Kovrovo cemetery, grave 183}

The inventory of grave 183 (original designation V3 [SMBPK/MVF, PM-A 0245/01, PDF: Seite 7-8]) included: '... a funeral urn, a crossbow fibula, a crossbow fibula with a long catch-plate, glass beads, melted fragments of a bronze object' (Tischler and Kemke 1902, p. 25) (Fig. 5).

According to the records in the archive of the PrussiaMuseum, a ceramic burial urn, two fibulae, a green glass bead and a melted bronze fragment were found under a regular round-shaped pavement on the grave (SMB-PK/ MVF, PM-A 0245/02, PDF: Seite 59).

${ }_{15}$ The record is illegible. 
A

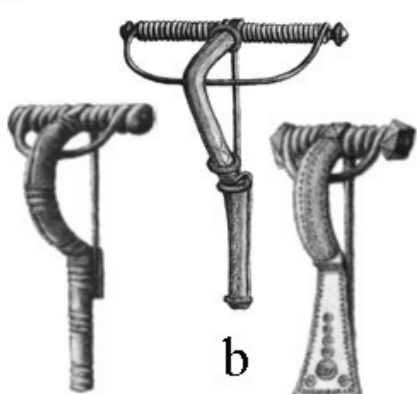

a $\mathrm{c}$

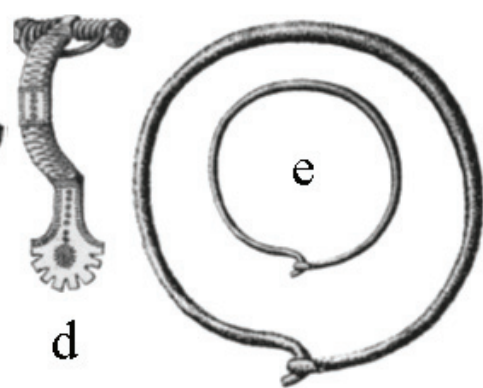

$\mathrm{h}$

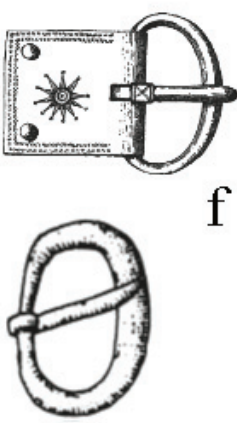

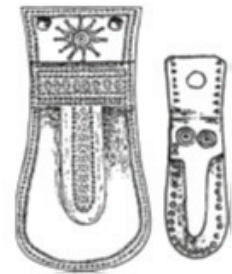

$\mathrm{g}$

B
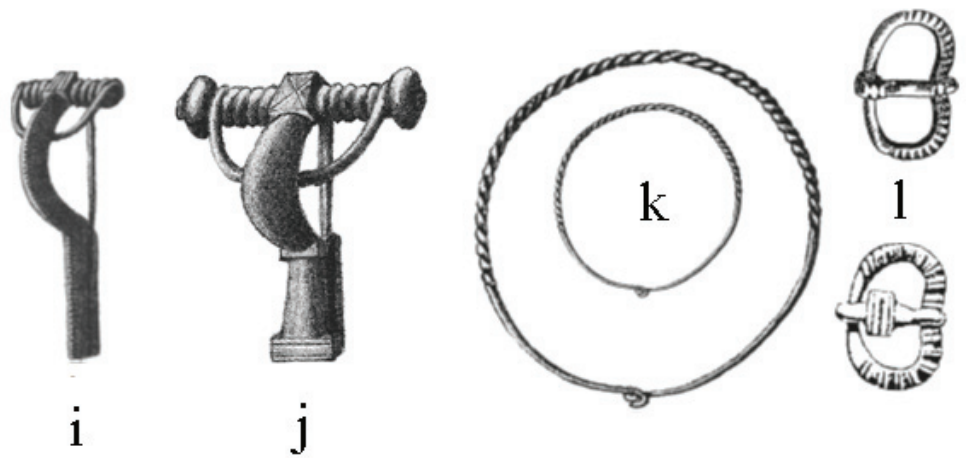

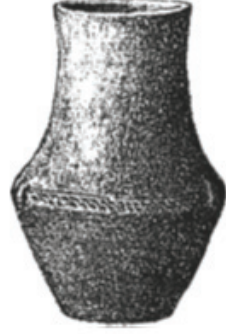

$\mathrm{m}$

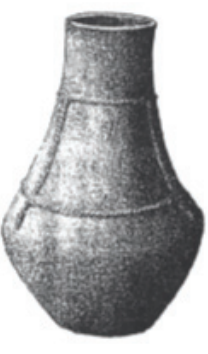

n

Figure 3. Joint finds of Schönwarling/Skowarcz and Dollkeim/Kovrovo-type crossbow fibulae with other chronotypes in graves in the SNC area. Not to scale. A. with Schönwarling/Skowarcz fibulae; B. with Dollkeim/Kovrovo fibulae. a. Schönwarling/Skowarcz fibula; b. large crossbow fibula with a bent foot (the ABF); c. trapeze-footed fibula; d. star-footed fibula; e. bracelet and neck rings with a round cross-section; f-g. belt buckles with a ferrule (H38 type) and strap ends, decorated in Sösdala-style; h. buckle with an oval, thickened frame (H11 type); i. Dollkeim/Kovrovo fibula; j. fibula with a crosspiece at the foot end; k. twisted bracelet and neck ring; l. belt buckles with a kidney-shaped frame (type III.1, variants a and d); m-n. ceramic vessels, types 8.1 and 8.2.

Data sources: a. Tischler and Kemke 1902, Table V.14; b. ibid., Table III.22; c. ibid., Table IV.12; d. ibid., Table IV.5; e. ibid., Table XV.11; f. Madyda-Legutko 1986, Table 20; g. ibid., Table 19; h. Tischler and Kemke 1902, Table XI.2,10; i. ibid., Table V.21; j. ibid., Table V.26; k. ibid., Table XV.13; l. Butenas 1999, Figs. 2.10, 16; m-n. Tischler and Kemke 1902, Tables XXIX.7, 16.

The first of the fibulae mentioned can be firmly identified on the basis of published illustrations as a representative of the S/S type. On the contrary, no solid confirmation could be found in the currently available sources for the assumption that the fibula 'with a long catch-plate' indeed belonged to the $\mathrm{D} / \mathrm{K}$ type.

As in the previous case, the complex can generally be dated to period $\mathrm{D}$, while the prerequisites for a more accurate dating of the inventory are currently absent.

\section{Warnikam/Pervomă̌skoe cemetery, grave 41}

The inventory of grave 41 (cremation), originally designated as grave 40 (SMB-PK/MVF, PM-A 0612/01, PDF: Seite 2 ; 16), included: '... three crossbow fibulae (one of which is depicted as IV16, with the second and third being similar to IV25 and V10 respectively), a damaged bracelet (similar to XV11), a biconic spindle, etc' (Tischler and Kemke 1902, p. 44).

According to data in the archive of the Prussia-Museum, a chamber of large stones was located under a double pavement of a nearly oval shape. A cluster of calcined bones was found among 'the remains of a fire' (probably a funeral pyre - note by the authors) at the center. The following grave goods were also found there: a bracelet (?), three fibulae, a fragment of a bronze object, a bronze buckle, blue glass beads (some of them damaged), an iron knife, and a bronze spiral (SMB-PK/MVF, PM-A 0612/01, PDF: Seite 2-3; 16) (Fig. 6).

Along with the list of finds, the excavation report contains a plan of the grave. The schematic depictions of the grave goods on the coloured plan enable additional observations. Thus, all items except the knife and the beads 


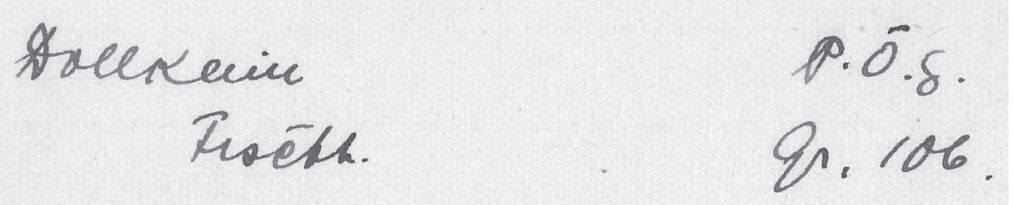

af on kurs Na. Ty. OK $\underline{T}: 11$.

af $m$ lug 12 abs $\nabla k \bar{L}: 21$.

hessu.

Pfricu

Bernstein perle

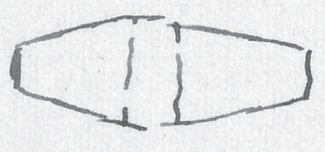

Sctuale, iss.

a

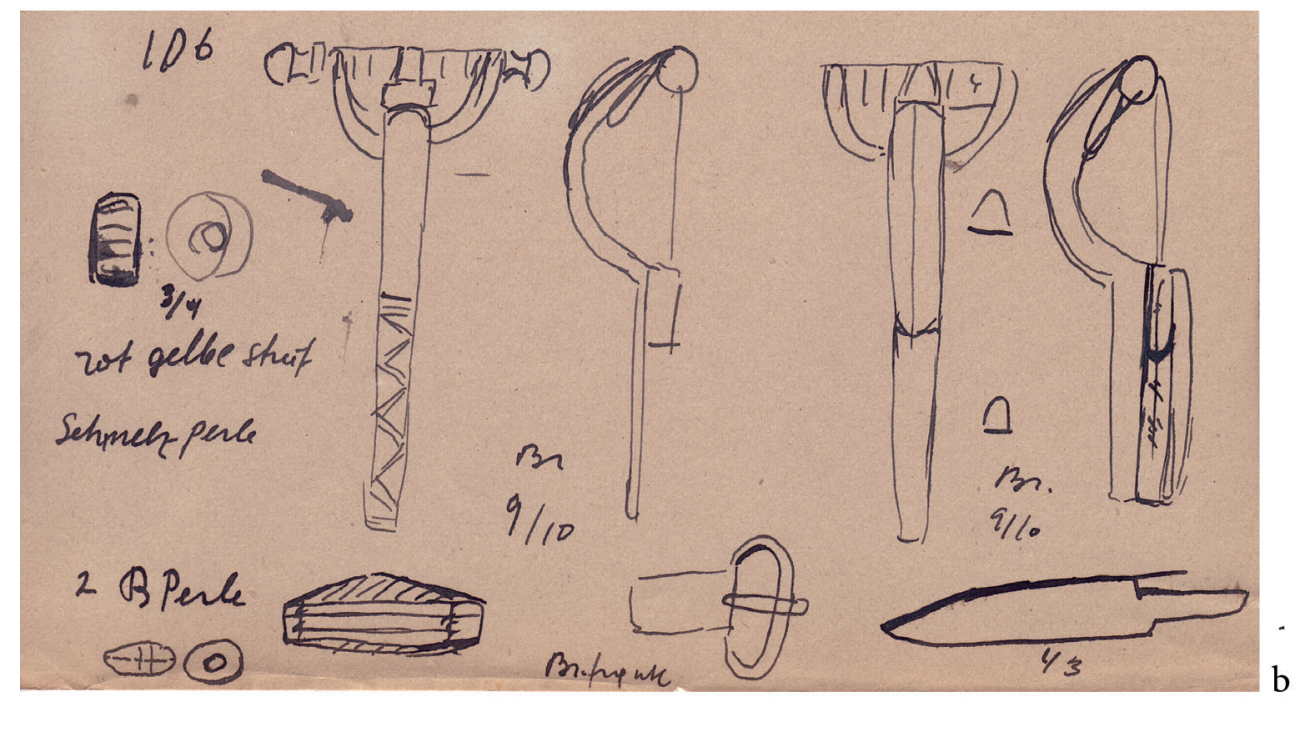

Figure 4. Grave 106, Dollkeim/Kovrovo: a. personal archive of Marta Schmiedehelm; b. personal papers of Felix Jakobson. 


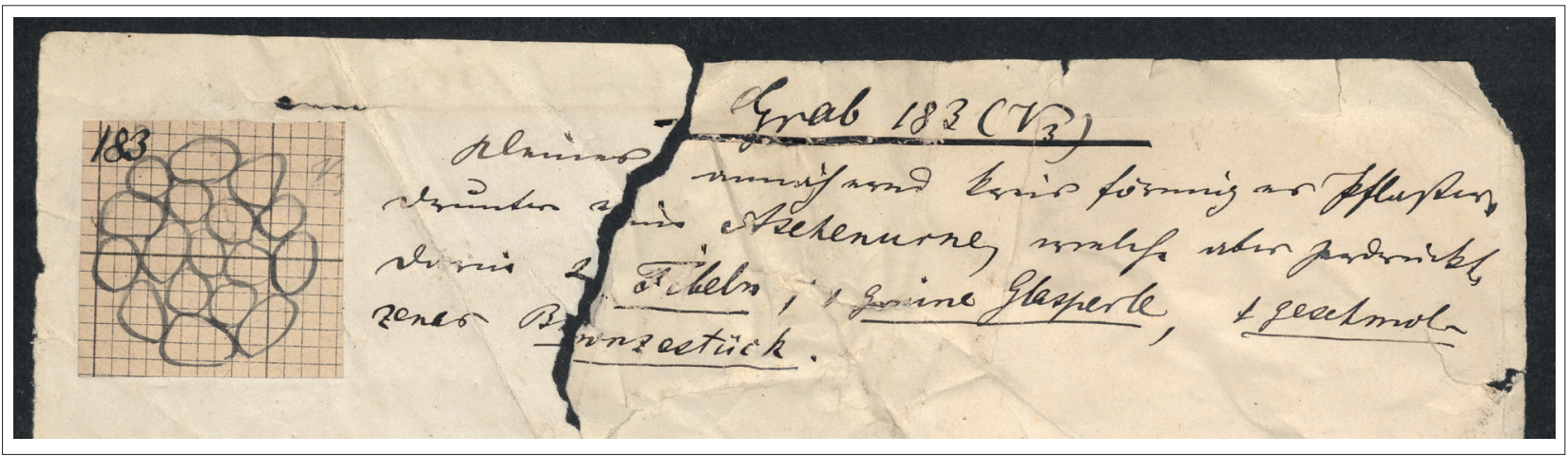

Figure 5. Grave 183, Dollkeim/Kovrovo: Prussia-Museum Archive.

were made of bronze, while the 'bracelet' is most likely a necklace with a round cross-section (type $\mathrm{H} 2$ according to Prassolow 2018, p. 64, Fig. 17). The small buckle is provided with a ferrule (probably type H17) (Madyda-Legutko 1986, p. 66, Fig. 19).

Necklaces and buckles similar to those in the grave were distributed in the SNC area throughout the whole period D (Prassolow 2018, pp. 56, 64).

The fibula published by Tischler and Kemke under the number IV16 is one of the variants of the trapeze-footed fibulae, which are characteristic of graves from the Late Roman period to the 1st half of phase D2 (Prassolow 2018, p. 50, Fig. 13), while the fibula under number V10 represents the S/S type (phases D1/D2-D2/D3).

In this context, a fibula similar (!) ${ }^{16}$ to the one depicted under the number IV25 is of great interest. It has indeed a number of traits in common with $\mathrm{D} / \mathrm{K}$ fibulae; however, it also demonstrates features that are unusual for this type. It has a thin, tapering leg, which ends with two spherical (?) segments, and a decorated transition of the bow to the foot, which resembles the attachment of the catch-plate of the typologically earlier fibula with a bent leg. These differences from 'classic' representatives of the type allow us to assume the find to be an early (?) type variant, which has been dated to the transition phase D2/D3. The grave as a whole should probably be assigned the same date. Thus, the complex, also, cannot serve as an example of common finds of 'classic' S/S and D/K fibulae.

\section{Warnikam/Pervomă̌skoe cemetery, grave 60}

\footnotetext{
${ }^{16}$ Practical experience of the comparative analysis of original finds with their description in prewar German sources demonstrates the necessity for extreme caution with regard to the claimed 'similarity' of artefacts, as far as such an assessment often appears to be very subjective. It is currently impossible to check whether the fibula from grave 41 was indeed typologically close to the one illustrated by Tischler and Kemke under the number IV25.
}

The inventory of grave 60 (cremation with the original designation 51 (SMB-PK/MVF, PM-A 0612/01, PDF: Seite $19 ; 27)$ ) included: '... three ceramic vessels, two crossbow fibulae (V25 and IV12), a crossbow fibula (similar to V9, but with a foot like V10), two buckles and strap ends (XI4, 5, 8 and 9 respectively), a melted silver strap end, and a shield boss (similar to those from graves 4 and 20, Table VIII15, published by Koenen 1 (892, Table VIII15) glass, enamel (including a bead with protrusions) and amber beads, etc' (Tischler and Kemke 1902, p. 44).

According to data from the archive of the Prussia-Museum (SMB-PK/MVF, PM-A 0612/01, PDF: Seite 19; 27-28), the grave was covered by a two-layer stone pavement (according to the sketch of seven and two stones, respectively). The inventory consisted of three ceramic vessels, an amber bead, an iron buckle, a bronze and a silver fibula, a second buckle, a silver object, whose function could not be identified on the basis of the description (belt fitting?), two belt tips, fragments of iron objects, and a cluster of beads. The list of grave goods in the archive was accompanied by their schematic depictions (Fig. 7b-c).

Additional sketches of grave goods in Jakobson's archive shed new light on the appearance and typological placement of the beads in the grave (Fig. 7a). In addition to the two amber beads, the complex obviously contained numerous glass beads: a disc-shaped brown (and another yellow?) bead with protruding eyes, as well as a green glass bead with protruding eyes, 11 reddish yellow barrelshaped beads, a light yellow and three red oval-shaped beads, and three blue cylindrical beads. The same complex contained four glass beads: two light blue, one red, and one light yellow. However, these beads, which had a cross/stellar shape, had no characteristic protruding eyes. Interestingly, while amber beads should, judging by the illustrations in the archive of the Prussia-Museum, be referred to as disc-shaped and hemispherical, in Jakobson's archive we see beads of a completely different form: oblong, spindle-shaped and disc-shaped (Fig. 7a). 


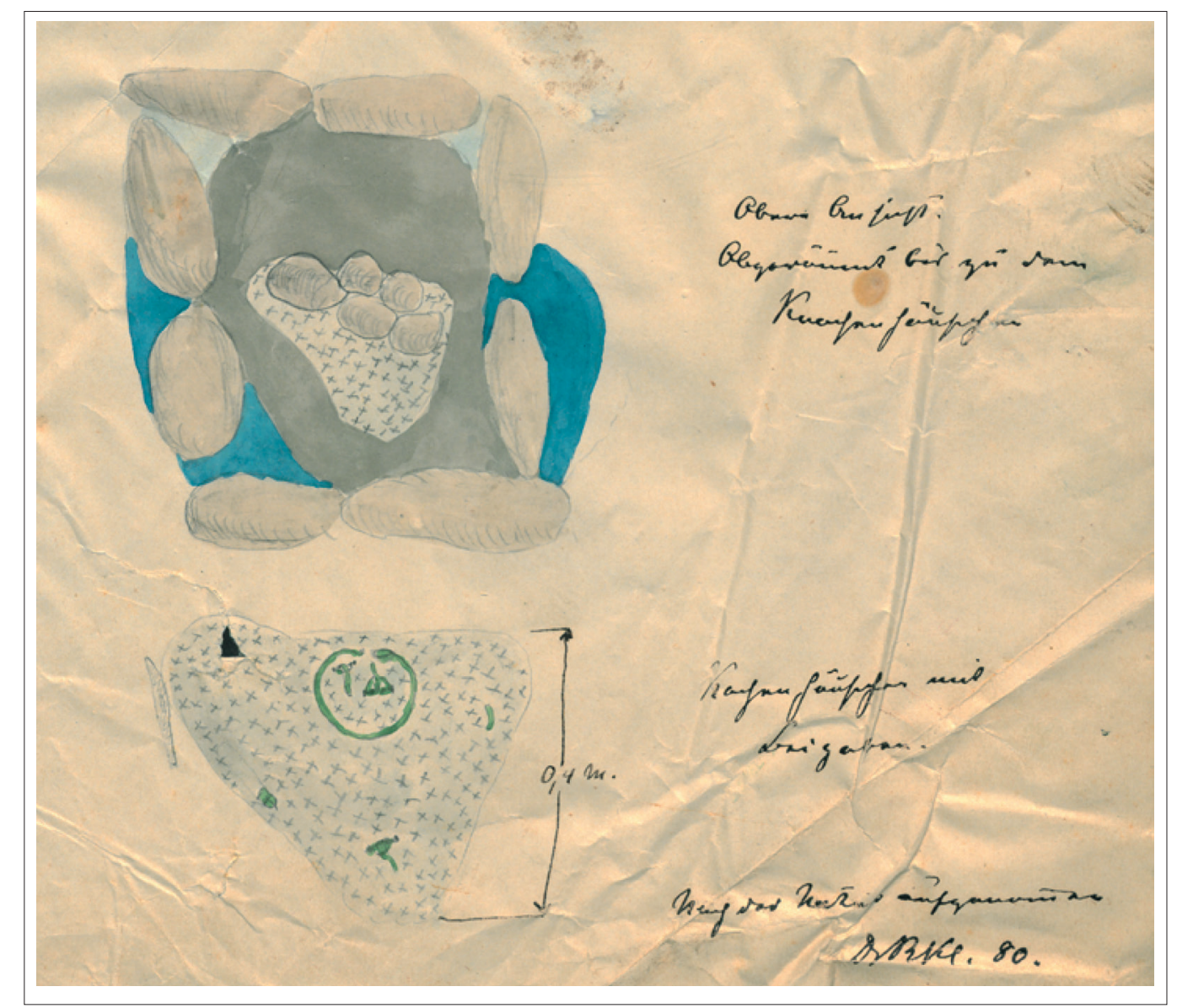

Figure 6. Grave 41, Warnikam/Pervomaĭskoe: Prussia-Museum Archive.

Fragments of a shield boss and a sickle are preserved today in the MVF, Berlin (PM Pr 19380 and Pr 19379 respectively).

Unfortunately, none of the above-mentioned objects really help to specify the grave's dating. ${ }^{17}$

That said, let us take a closer look at the fibulae from the grave. One of them is a classic example of a trapeze-footed fibula. As is noted above, these are characteristic of complexes from the Late Roman period to the first half of the Early Migration period, and, as in this specific case, are often found in graves together with S/S fibulae (Table 1). It is, however, the third fibula that is of special interest in the context of the actual discussion. Based on the prewar depiction of the artefact, Bitner-Wróblewska identified it as a fibula with a crosspiece at the foot end (Tischler and Kemke 1902, Table V.25; Bitner-Wróblewska 2001, p. 39, Table IV.4).

Indeed, in the prewar German publication, this fibula looks intact, and its above-mentioned typological place-

\footnotetext{
${ }^{17}$ Most of the above-mentioned beads can be easily determined according to the typology developed by Magdalena Tempelmann-Maczyńska (1985), which unfortunately provides no help for the fine dating of the burial complexes in question.
}

ment seems to be beyond doubt. However, a careful study of its depiction in Jakobson's archive provides quite new and unexpected details concerning the typology of this object. ${ }^{18}$ We can clearly see that a small, trapezoid platform at the end of the foot has an uneven bottom edge, which marks the place of breakage. The specimen also differs from true fibulae with a T-shaped foot end, in that it has a decorative platform-metope on its bow (Fig. 6). Everything points to the fact that the artefact in question is a damaged star-footed fibula, which from the point of view of comparative chronology, ideally correlates with the presence of two other fibulae of the 'early horizon' in the grave. This conclusion implies that the grave complex automatically turns out to be outside the scope of the ongoing discussion.

${ }^{18}$ As for the reliability of the prewar research data, BitnerWróblewska's remark is indicative and true: 'One should not forget that the data on Samland's finds and all the material from the former East Prussia bases on drawings and descriptions, more often only on descriptions rather than on original finds ... (2001, p. 45). 


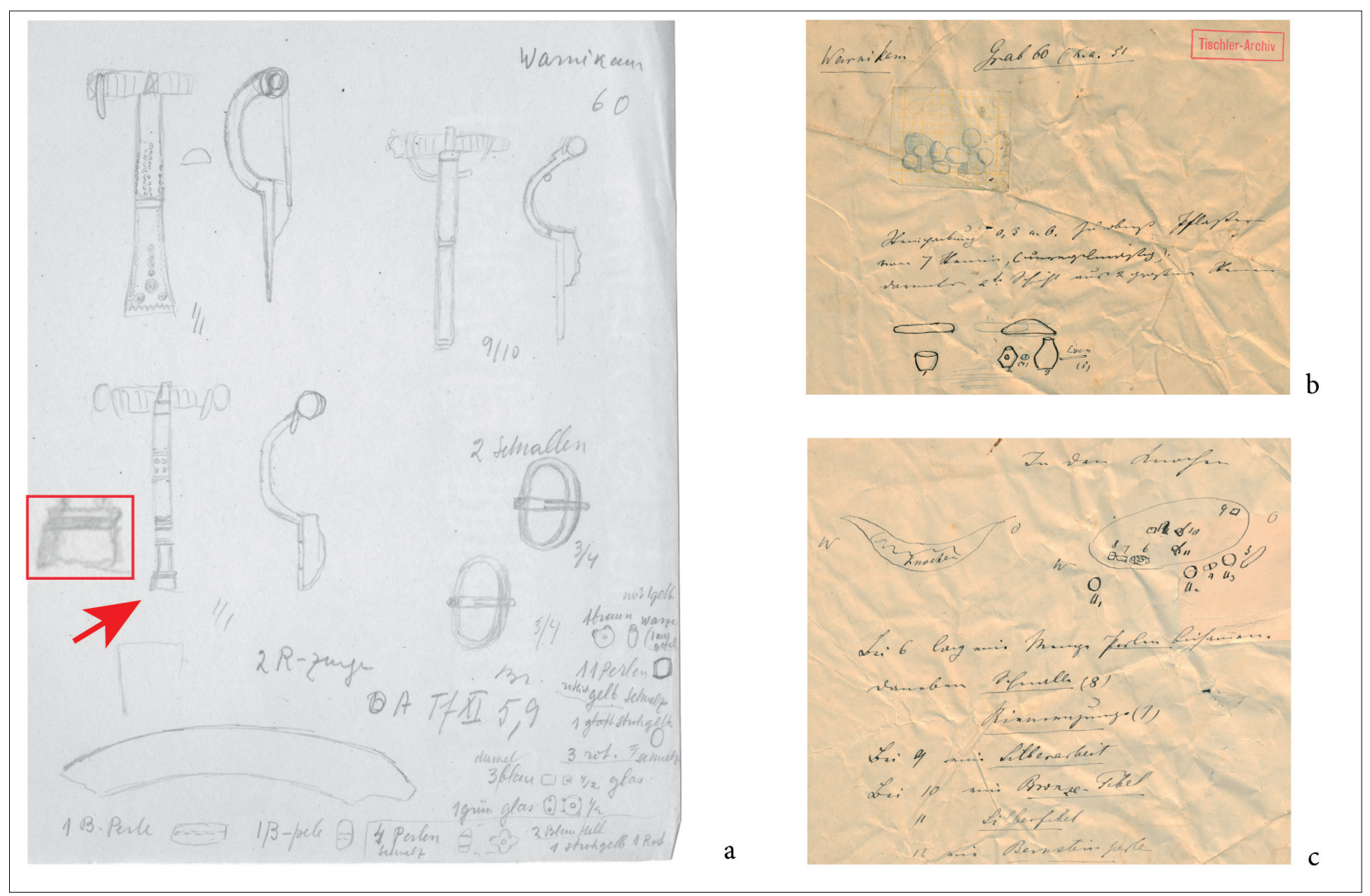

Figure 7. Grave 60, Warnikam/Pervomă̌skoe: a. personal papers of Felix Jakobson; b-c. Prussia-Museum Archive.

\section{Conclusions}

As we have seen, only one (perhaps two) of the four grave complexes that formed the basis for the hypothesis about the contemporary use of the $\mathrm{S} / \mathrm{S}$ and $\mathrm{D} / \mathrm{K}$ fibulae in the SNC area contain representatives of both types at the same time. Thus, these data do not contradict our modern observations concerning the extremely rare co-occurrence of $\mathrm{S} / \mathrm{S}$ and $\mathrm{D} / \mathrm{K}$ fibulae in graves.

Instead, they indirectly confirm our conclusion about the natural replacement of $\mathrm{S} / \mathrm{S}$ fibulae by those of $\mathrm{D} / \mathrm{K}$ type.

The abrupt change of archaeological material in a certain region usually reflects a displacement of the local population by the carriers of another cultural tradition, or similar cultural cataclysms.

On the contrary, in the case of a natural diachronic change of an archaeological culture, the transitional process is reflected in the similarly smooth alteration of the composition of grave inventories. It therefore seems to be quite natural that some graves (including those of senile individuals) will contain artefacts that belong to different, but bordering, phases of the archaeological culture in question.

The interpretation of joint finds of certain artefacts in archaeological complexes should thus not only consider the fact of the existence of such cases alone, but also their to- tal number. It should be borne in mind that when we try to identify the chronological framework of S/S and D/K fibulae, we are dealing with time segments of only 10 to 20 years, which in the case of non-violent diachronic changes in the culture are usually only barely perceptible by archaeological means.

The statistics concerning cases where S/S fibulae were found together with fibulae that are characteristic of the Late Roman period, i.e. with large crossbow fibulae with a bent foot and trapeze-footed fibulae, should be taken into account when defining the low chronological limit of S/S fibulae use. The presence of S/S fibulae in the 'early' graves of the Early Migration period has so far been explained by the fact that they had already emerged by the end of the 4th century (phase C3/D1) (Bitner-Wróblewska 2001, pp. 39-40, Pl. LIX). Comparative material analysis implies, however, that these joint finds should rather be explained through the long-term use of single specimens of Roman period fibulae, whose presence led to the false early dating of the grave inventories in question.

Similarly, based on the results of a comparative analysis of archaeological material in the SNC area, single cases of common finds of $\mathrm{S} / \mathrm{S}$ and $\mathrm{D} / \mathrm{K}$ fibulae should be explained by the long-term use of single $S / S$ fibulae, which were otherwise already old-fashioned, i.e. out-of-use, at the moment of their deposition in the graves in question (Table 
1). Taking into account all the above-mentioned considerations, we date the majority of S/S fibulae to phases D1/ D2-D2, while admitting that certain specimens could have remained in use up to phase D3. On the other hand, no $\mathrm{D} / \mathrm{K}$ fibulae are present in the burial complexes that are dated earlier than D2/D3 to the beginning of phase E1. ${ }^{19}$ It can be said with a high degree of reliability that $\mathrm{D} / \mathrm{K}$ fibulae not only stayed in use a little longer (until D3/E1) than S/S fibulae, but also appeared later than was previously believed, in fact, replacing them. This natural replacement of S/S fibulae by those of $\mathrm{D} / \mathrm{K}$ type took place in the transition phase $\mathrm{D} 2 / \mathrm{D} 3$, i.e. about $430 \mathrm{AD}$.

The results obtained will allow for a much more precise dating of SNC grave complexes in the absence of other chronotypes of the Migration period.

\section{Abbreviations}

$\mathrm{D} / \mathrm{K}$ - fibula of Dollkeim/Kovrovo type

S/S - fibula of Schönwarling/Skowarcz type

SNC - Sambian-Natangian culture

MS-A - personal papers of M. Schmiedehelm

FJ-A - personal papers of Felix Jakobson

KS-A - personal papers/field reports of K. Skvortsov

\section{References}

\section{Manuscripts}

Prassolow, A.V. 2017. Report on the archaeological investigations performed in the year 2007 by the Sambian archaeological expedition of the IA RAN on the flat cemetery at Shosseinoe (Gur'evskil district of the Kaliningrad Region of the Russian Federation). Archive of the IA RAN R-1. № 31145

Skvortsov, K.N., 1996. Report on the investigations, performed by the Natangian team of the Baltic expedition of the IA RAN in the year 1995. Archive of the IA RAN, R-I № 191901.467.

Skvortsov, K.N., 1997. Report on the investigations, performed by the Natangian team of the Baltic expedition of the IA RAN in the year 1996. Archive of the IA RAN, R-I № 20266.

Skvortsov, K.N., 1999. Report on the archaeological excavations performed by the Natangian team of the BAE of IA RAN on the cemetery at B. Isakovo-Lauth in the year 1998. Archive of the IA RAN, R-I № 21982.

Skvortsov, K.N., 2000. Report on the archaeological excavations performed by the Natangian team of the BAE of IA RAN on the cemetery at B. Isakovo-Lauth in the year 1999. Archive of the IA RAN, R-I № 23284 .

Skvortsov, K.N., 2001. Report on the archaeological excavations performed by the Sambian-Natangian archaeological expedition on the flat cemetery at Bol'shoe Isakovo in the year 2000. Archive of the IA RAN, R-I № 24732.

${ }^{19}$ It is indicative that similar conclusions were drawn by the Polish researcher Pawel Szymański with regard to the fibulae in question in the area of the 'Gołdap group' (2018, pp. 113114, Table LXXXIII).
Skvortsov, K.N., 2003. Report on the archaeological excavations performed by the Natangian team of the BAE of the IA RAN on the cemetery at B. Isakovo-Lauth in the year 2002. Archive of the IA RAN, R-I № 25795 .

Skvortsov, K.N., 2004. Report on the archaeological excavations performed by the Sambian-Natangian archaeological expedition on the flat cemetery at Lauth-Bol'shoe Isakovo in the year 2003. Archive of the IA RAN, R-I № 25796.

Skvortsov, K.N., 2008. Report on the archaeological excavations performed by the Sambian expedition in the year 2007. Cemetery at Shosseinoe/Warthen in the Kaliningradskaia Oblast' of $R F$. Archive of the IA RAN, R-I, no number.

\section{Literature}

Åberg, N., 1919. Ostpreussen in der Völkerwanderungszeit. Uppsala: Almqvist \& Wiksells Boktryckeri-A.-B.

Almgren, O., 1897. Studien über nordeuropäische Fibelformen der ersten nachchristlichen Jahrhunderte. Stockholm: Haeggström.

Bitner-Wróblewska, A., 1991a. Between Scania and Samland. From studies of stylistic links in the Baltic basin during the Early Migration Period. Fornvännen, 86, 225-241.

Bitner-Wróblewska, A., 1991b. Zapinki z gwiaździstą i łopatkowatą nóżką z południowo-wschodnich wybrzeży Bałtyku. Wiadomości Archeologiczne, LI /1 (1986-1990), 4990.

Bitner-Wróblewska, A., 1991c. The southeastern Baltic zone and Scandinavia in the Early Migration Period. Barbaricum, 2, 245-277.

Bitner-Wróblewska, A., 1992. Crossbow Brooches from the Eastern Baltic Basin in the Early Migration Period. The import of ideas or objects? In: B. Hårdh and B. Wyszomirska-Werbart, eds. Contacts across the Baltic Sea during the Late Iron Age (5th-12th centuries), Baltic Sea Conference. Lund: Institute of Archaeology, 27-36.

Bitner-Wróblewska, A., 2001. From Samland to Rogaland. EastWest connections in the Baltic basin during the Early Migration Period. Warszawa: Panstwowe Muzeum Archeologiczne.

Butènas, E., 1999. Sagtys iš Rytų Lietuvos pilkapių (tipai, paskirtis). Lietuvos archeologija, 18, 37-57.

Godłowski, K., 1970. The chronology of the Late Roman and Early Migration Periods in Central Europe. Prace Archeologiczne, 11. Kraków: Nakładem Uniwersytetu Jagiellonśkiego.

Godłowski, K., 1974. Chronologia okresu późnorzymskiego i wczesnego okresu wędrówek ludów w Polsce północnowschodniej. Rocznik Białostocki, 12, 9-107.

Günther, C. and Voss, A., 1880. Photographisches Album der Ausstellung Praehistorischer und Archaeologischer Funde Deutschlands. Section I: Ost- und Westpreußen. Berlin: Berg \& von Holten.

Gusakov, M.G., Kulakov, V.I. and Popova, V.M., 1987. Raboty v okrestnostiah g. Pionerskil. Arkheologicheskie otkrytiia 1985 g. [Investigations in the vicinity of Pionerski1. Archaeological discoveries of the year 1985]. Moskva: Nauka, 9-10.

Kemke, H., 1914. Kritische Betrachtungen über Tischlers Periode «E» der ostpreussischen Gräberfeldern. Sitzungsberichte der Altertumsgesellschaft Prussia, 23 (1), 1-57.

Koenen, C., 1892. Aufdeckung einer vorgeschichtlichen Niederlassung und eines fränkischen Gräberfeldes in Meckenheim. Jahrbücher des Vereins von Altertumsfreunden im Rheinlande, 92, 147-218.

Kowalski, J., 1991. Z badań nad chronologią okresu wędrówek ludów na ziemiach zachodniobałtyjskich (faza E). In: H. Judzińska, ed., Archeologia Bałtyjska: materiały z konferencji, 
Olsztyn, 24-25 kwietnia 1988 roku. Olsztyn: Ośrodek Badań Naukowych im. Wojciecha Kętrzyńskiego, 67-85.

Kulakov, V.I., 1990. Drevnosti prussov VI-XII v.v. [Antiquities of the Prussians: 6th-13th Centuries A.D.] SAI, vypusk G 1-9. Moscow: Nauka.

Kulakov, V.I., 1994. Gora Velikanov: raskopki 1992 g. [Giants mountain (Hünenberg): excavations in 1992]. Barbaricum, 3, 47-61.

Kulakov, V.I., 2003. Istoriia Prussii do 1283 g. [History of Prussia to the year 1283]. Moscow: Indrik.

Kulakov, V.I., 2014. Hünenberg - "Gora Velikanov". Mogil'nik III-IV vv. na severe Sambii. [Hünenberg - „Mountain of Giants". Cemetery of the 3rd-4th Century in the North of Sambia]. In: B. Kontny, A. Wisniewska, A. Juga-Szymanska, A. Jare-Mek, eds. Barbaricum, 10, 199-362.

Kulakov, V.I., 2007. Dollkaĭm-Kovrovo. Issledovaniia 1992-2002 gg. [Dollkeim-Kovrovo. Investigations 1992-2002]. PrussiaAntiqua, 4. Minsk: Institute of History of NAN of Belarus.

Kulakov, V.I., 2017. Gora Velikanov: istok Iantarnogo puti [Hünenberg, the Mountain of Giants: the origin of the Amber road]. Pionerskiǐ: Kaliningrad book.

Kulakov, V.I. and Skvortsov, K.N., 2000. Boevye klinki iz Kliănnhaĭde. Gistarychna-archealagichny zbornik [Battle Blades from Kliaĭnhaĭde. Historical-Archaeological Digest], 15, 40-52.

Kulakov, V.I. and Tiurin, E.A., 2005. Kompleksy 5 v. n. eं mogil'nika Gora Velikanov, Rossiǔskaia archeologiüa [Burial Complexes of the 5th Century from the Burial Site Hünenberg, the Mountain of Giants. Russian Archaeology], 2, 115131

Madyda-Legutko, R., 1986. Die Gürtelschnallen der Römischen Kaiserzeit und der frühen Völkerwanderungszeit im mitteleuropäischen Barbaricum. BAR International Series, 360. Oxford: BAR.

Nowakowski, W., 1996. Das Samland in der römischen Kaiserzeit und seine Verbindungen mit dem römischen Reich und der barbarischen Welt. Veröff. Vorgesch. Seminar Marburg, Sonderbd. 10. Marburg, Warszawa: Druk.

Okulicz, J., 1973. Pradzieje ziem pruskich öd pöznego palcolitu do VII w.n.e. Wrocław: Zakład Narodowy im. Ossolińskich.

Okulicz, J., 1988. Problem ceramiki typu praskiego w grupie olsztyńskiej kultury zachodniobałtyjskiej (VI-VII w n.e.). Pomorania Antiqua, XIII, 103-131.

Prassolow, J.V., 2013. K voprosu ob ispol'zovanii pereviazeĭ tipa balteus Vidgiriai na territorii sambiǔsko-natangiǔskoĭ gruppy v 4.-5. vv. n. è. [To the question of distribution of shoulderstraps of type balteus Vidgiriai on the territory of SambianNatangian culture in the 4th-5th centuries AD]. In: N.A. Makarov, A.V. Mastykova and A.N. Khokhlov, eds. International conference "Archaeology of the Baltic: New Discoveries and studies", November 2010. Kaliningrad-Moscow, SaintPetersburg: Nestor-Historia, 80-96.

Prassolow, J.A., 2018. Die völkerwanderungszeitlichen Dolchmesser der samländisch-natangischen Kultur auf dem Gebiet des ehemaligen Ostpreußens. Studien zur Siedlungsgeschichte und Archäologie der Ostseegebiete, 15. Kiel: Wachholtz Verlag.

Rudnicki, M., 2008. Bemerkungen zur Entwicklung von Armbrustsprossenfibeln aus dem Territorium der Olsztyn-Gruppe. Erste Feststellungen. In: B. Niezabitowska-Wiśniewska, M. Juściński, P. Łuczkiewicz and S. Sadowski, eds. The Turbulent Epoch. New Materials from the Late Roman Period and the Migration Period, II. Lublin: Wydawnictwo Uniwersytet Marii Curie-Skłodowskiej, 291-302.

Schulze-Dörrlamm, M., 1986. Romanisch oder germanisch? Untersuchungen zu den Armbrust- und Bügelknopffibeln des 5. und 6. Jahrhunderts n. Chr. aus den Gebieten westlich des
Rheins und südlich der Donau. Jahrbuch der Römisch-Germanischen Zentralmuseums, 33 (2), 593-720.

Skvortsov, K.N., 2010. Mogil'nik Mitino 5.-14. vv. (Kaliningradskaia Oblast'). Po rezul'tatam issledovaniǐ 2008 goda Burial site Mitino of the 5th-14th century (Kaliningrad Region of Russia). Results of Archaeological Investigation in the Year 2008. Vol. 1. Moscow: Institute of Archaeology RAN.

Skvorzov, K.N., 2007. Das Gräberfeld der römischen Kaiserzeit von Bolšsoe Isakovo (ehemals Lauth, Kreis Königsberg). Katalog der Funde aus den Grabungen 1998 und 1999. Offa, 61/62, 111-220.

Szymański, P., 2018. Chronologia gołdapskiej grupy kulturowej w okresie wędrówek ludów. Światowit Supplement Series P: Prehistory and Middle Ages, 20. Warszawa: Instytut Archeologii Uniwersytetu Warszawskiego.

Tempelmann-Maczyńska, M., 1985. Die Perlen der römischen Kaiserzeit und der frühen Phase der Volkerwanderungszeit im mitteleuropäischen Barbaricum. Mainz am Rhein: Philipp von Zabern Verlag.

Tischler O. and Kemke H., 1902. Ostpreußische Altertümer aus der Zeit der grossen Gräberfelder nach Christi Geburt. Königsberg i. Pr.: Koch i. Komm.

\section{SEMBOS-NOTANGOS KULTÜRINIO AREALO SCHÖNWARLING / SKOWARCZ IR DOLLKEIMO / KOVROVO TIPO LANKINÉS SEGËS}

\section{JAROSLAW A. PRASSOLOW, KONSTANTIN SKVORTSOV}

\section{Santrauka}

Šis straipsnis skirtas Schönwarling / Skowarcz ir Dollkeimo / Kovrovo tipo lankinèms segèms su ilga siaura kojele ir skirtingo ilgio užsegimo užkabomis $(1 \text { pav. })^{20}$. Tokio tipo segès yra vienas iš charakteringiausių chronologinių indikatorių radinių tipų tautu kraustymosi laikotarpio Sembos-Natangos kultūriniame areale (dabar Kaliningrado regionas, Rusijos Federacija) (2 pav.). Autoriai analizuoja specifinius konstrukcinius segiu elementus vietinès kultūros kontekste, ir tai leidžia apibrěžti jų tipologiją (1 pav.). Segių chronologija buvo sudaryta 1990 m., paremta ikikariniais vokiškais regiono tyrimais ir publikacijomis. Per XX a. buvo sukaupta didelè naujų radinių kolekcija, kuria papildyta senoji tipologine sistema. Taip pat buvo atrasta per Antrajji pasaulinį karą dingusi archyvinè medžiaga, kuri ilgą laiką laikyta sunaikinta ir prarasta amžiams. Naujos archeologinès medžiagos ir archyvinių dokumentu analizè suteikia galimybe kokybiškai naujai ir tiksliai patikrinti egzistuojančias hipotezes. Tokia analizė Sembos-Notangos kultūros kontekste atlikta pirmą kartą.

${ }^{20}$ Lietuviškoje istoriografinèje tradicijoje abu šių lankinių segių tipai vadinami lankinèmis ilgakojèmis segèmis su lieta užkaba (redaktorinè pastaba). 
Atlikus archeologinès ir archyvinès medžiagos komparatyvinį tyrimą, straipsnio autoriai pateikia patikslintą Schönwarling / Skowarcz ir Dollkeimo / Kovrovo tipų lankinių segių chronologiją. Tyrimas parodè, kad populiari šių tipų koegzistavimo hipotezè nèra tiksli - nauji duomenys rodo, kad Schönwarling / Skowarcz segès pamažu D2/D3 periodu (apie $430 \mathrm{AD}$ ) buvo pakeistos Dollkeimo / Kovrovo tipo segemis. Atskleista nauja šių segių chronologija ateityje suteiks galimybę datuoti kapų kompleksus net ir jei nebus rasta kitų patikimai datuojamų radinių. 